\title{
Simplicius on the Individuation of Material Substances
}

\section{Introduction}

What makes an individual an individual $?^{1}$ This question has received enormous attention in modern debates on Aristotle ${ }^{2}$ - curiously enough, one might say, given that Aristotle does not use a term like individuation (or individuate), let alone develop an elaborate theory of it. ${ }^{3}$ On the other hand, it is likewise remarkable that already the ancient commentators on Aristotle investigate Aristotle's ideas of how the individual is constituted. They address individuation in a much more straightforward way than the Stagirite does. ${ }^{4}$

Simplicius of Cilicia, who in the $6^{\text {th }}$ century A.D. stands at the end of the late ancient commentary tradition, speaks of individual forms that individuate matter. Since in the same text (In Phys. I 9) he calls immanent form universal, it seems reasonable to conclude that the individual forms are individual instances of one universal species-form. However, Simplicius here also mentions accidental properties that are peculiar to form rather than to matter. On the basis of Simplicius' commentaries on the Categories and on the Physics, I will argue that the individuating accidents are not part of the individual forms, but that each individual's form coordinates the individual's accidental features. By belonging to a certain species, the individual form sets limits as to which accidents a matter-form compound can assume. This approach enables Simplicius to combine hylomorphism with a theory of individuation

\footnotetext{
*Corresponding author: Marina Schwark, Philosophisches Seminar, Universität zu Köln, Köln, Germany/Hoger Instituut voor Wijsbegeerte, KU Leuven, Leuven, Belgium; E-mail: mschwark@ smail.unikoeln.de. - I would like to thank all of those who gave me the opportunity to present earlier versions of this paper or of parts of it: in Heidelberg on May 9, 2016 (chapter 3); in Leuven on June 8, 2017; in Cologne on June 26, 2017; and again in Leuven on November 16, 2017 (chapter 3). The vivid discussions on these occasions greatly helped me develop my ideas. Special thanks are due to Christoph Helmig and Jan Opsomer for their detailed comments. I am further indebted to the two referees of Elenchos for their stimulating remarks. Lastly, I thank Peter Larsen and Philip Kupferschmidt for proofreading the English text.

${ }^{1}$ As the title of my paper suggests, I restrict my discussion to the individuation of material substances. I thus leave aside the question of how rational souls and celestial intelligences are individuated.

${ }^{2}$ For more recent studies on individuation in Aristotle, see, e.g., Fine (2001); Gill (2001); Castelli (2003); Cho (2003) 88-91, 297-303; Galluzzo/Mariani (2006) 70-74 and 167-211, each with further literature; Kirby (2008) 9-44; Harte (2010); Castelli (2013) 162-166; Galluzzo (2013) 234-242. For a concise overview of the debate on individuation in contemporary analytic metaphysics, see Lowe (2003).

${ }^{3}$ As Galluzzo (in Galluzzo/Mariani 2006) 73 puts it: "one is forced to acknowledge that the evidence in favour of attributing to Aristotle a genuine and independent interest in the problem of individuation is very little."

${ }^{4}$ On Alexander of Aphrodisias, see the article by Rashed (2010). Of the later authors, only Porphyry's theory of the individual as a bundle $(\alpha \theta \rho o \imath \sigma \mu \alpha)$ has received proper attention (see Graeser 1996, 190-193; Chiaradonna 2000; Barnes 2003, 150-154, 314-316, 342-345; Sorabji 2004, 169-171; Chase 2011, 22-24). See section 2 for more on this. Erismann (2014) mainly focuses on the status of universals in Philoponus. The problem of individuation is merely touched upon (see Erismann 2014, 143-144, 146-147, 156). Apart from the commentaries on Aristotle, late ancient authors also discuss individuation in independent treatises and commentaries on Plato. There is a considerable scholarship on individuation in Plotinus, see Aubry (2008) and Chiaradonna (2014), each with further literature.
} 
through properties. I will further show that Simplicius in his commentary on De Caelo I 9 explains the non-repeatability of the individuating properties in light of his Neoplatonic cosmology.

My paper proceeds in four main steps. Section 1 is devoted to Simplicius' commentary on Physics I 9, where he claims that individual forms individuate matter. Here I will clarify the sense in which Simplicius speaks of individual forms as opposed to the universal immanent species-form. In a second step I will argue that Simplicius combines Aristotelian hylomorphism with a theory of individuation through properties. Section 3 then further elucidates the relation between substantial form and individuating properties. In the last part of my paper, I will examine Simplicius' commentary on De Caelo I 9, where he explains the distribution of the individuating properties in the context of his Neoplatonic cosmology.

\section{A puzzle about individual forms: In Phys. I 9}

In his commentary on Physics I 9, 253.28-256.13, Simplicius is concerned with Aristotle's proof that matter is ungenerated and imperishable. After systematically analyzing the proof, Simplicius argues that individual matter perishes just like individual form. In this context, he mentions individual forms that individuate matter. This statement is interesting, especially since Simplicius in the same passage mentions universal immanent forms, i.e., universal mind-independent forms in rebus. In what follows, I will first outline Simplicius' argument and then elucidate the role of form in individuation. In doing so, I will investigate the sense in which the individual forms are individual. That is, I will examine whether they are merely numerically distinct or whether they are also qualitatively distinct. ${ }^{5}$

At In Phys. I 9, 253.28-256.13, Simplicius explains how we should understand Aristotle's thesis that matter is ungenerated and imperishable. In this context, Simplicius compares matter to form. Just as common matter is ungenerated and imperishable, so too is common form: "But this [sc., being common] also applies to the forms, since the commonality of any form is not destroyed out of the universe, but there is always human and horse and white and virtue and each of the other forms because the commonality of each of them endures." 6

\footnotetext{
${ }^{5}$ For the sake of convenience, I adopt this terminology from Loux. Loux (1991) 225-228 distinguishes between quantitatively different forms and qualitatively different forms. Quantitatively different forms differ merely numerically, while qualitatively different forms differ insofar as they possess different properties (properties not in the sense of spatiotemporal properties). Loux's terminology is influenced by debates in contemporary metaphysics. Loux apparently does not use the term qualitative in the Aristotelian sense, i.e., he does not want to suggest that two forms differ with regard to the accidental category quality, and with regard to this category only.

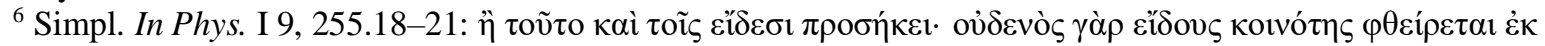

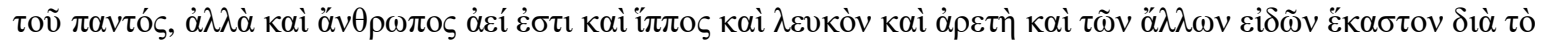


Simplicius argues that the forms in question exist in the universe ( $\tau$ ò $\pi \tilde{\alpha} v$ ). The context, too, indicates that Simplicius is thinking of immanent forms in the sense of mind-independent universalia in rebus. As we have seen, Simplicius is primarily concerned with matter, and, unlike immanent forms, neither transcendent Forms nor abstracted universals are directly related to matter. Thus, we can conclude that Simplicius draws a parallel between matter and immanent forms. Interestingly, Simplicius does not confine himself to substantial forms, but includes qualities such as white and virtue as well.

After having stressed that common matter, like common form, is imperishable, Simplicius extends his inquiry. He explains that we can conceive of matter in two ways. On the one hand, we can think of it insofar as it is matter in itself, and this means insofar as it is common. On the other hand, we can pick out the matter of a certain thing - qualified matter, that is, as Simplicius describes it: "insofar as it is my matter and matter of such and such a sort." "Is this particular matter ungenerated and imperishable? Simplicius identifies two problems that would arise if this were the case. ${ }^{8}$ First, particular matter would have no purpose once the form would have perished. When my form perishes, it does not make sense for my matter to remain..$^{9}$ A second absurdity Simplicius mentions is that if individual matter were ungenerated and imperishable, this would make matter superior to and more substantial than form. Simplicius here explicitly relies on the premise that particular forms come to be and perish. ${ }^{10}$ Simplicius introduces his own solution with the particle $\mu \eta \dot{\pi} \tau \varepsilon \varepsilon .{ }^{11}$ "Perhaps then matter in itself is not individual, but it is individualised by individual forms just as it is shaped by

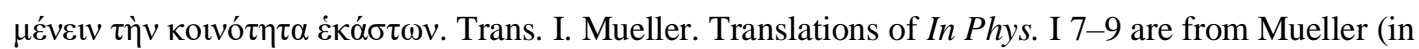
Baltussen/Atkinson/Share/Mueller, 2012), except when otherwise indicated.

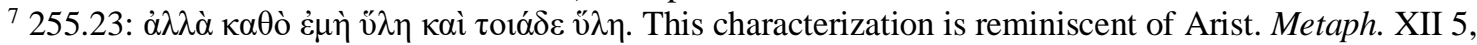
1071a24-29, where Aristotle explains differences in causes. The causes of things that belong to different categories differ specifically and are the same only by analogy. By contrast, the causes of things that belong to the same category differ numerically, as becomes evident from the opposition between your matter, form, and efficient cause and mine.

${ }^{8}$ Although Simplicius does not mention Alexander of Aphrodisias or his followers, it seems that the arguments respond to the position that is held in Quaestio II 28. (On the authorship of the Quaestiones, see Sharples 1994, 2-3; on the authorship of Quaestio II 28 in particular, see Lloyd 1981, 60. For the sake of simplicity, I call Alexander the author of Quaestio II 28.) When investigating the difference between genus and matter, Alexander

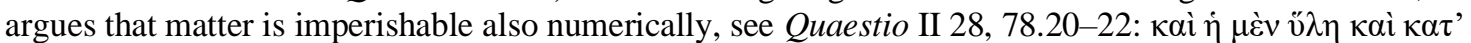

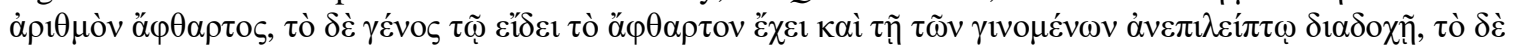

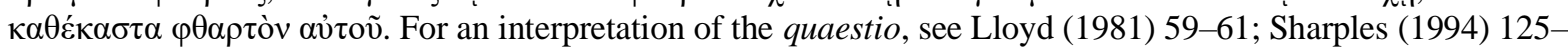
126 n. 168, 126 n. 174; Rashed (2007) 94-104.

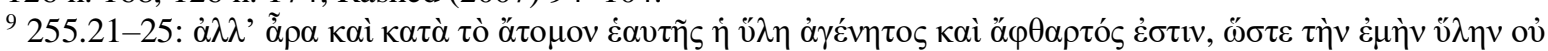

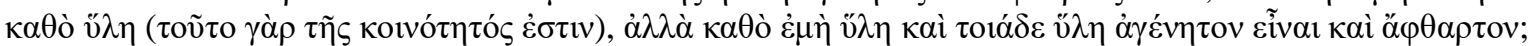

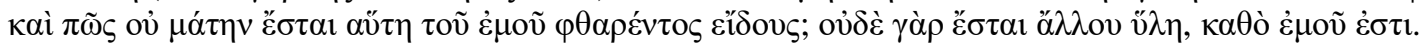

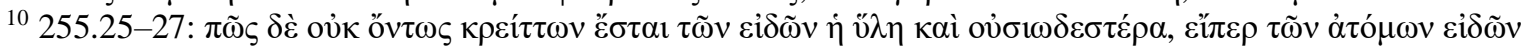

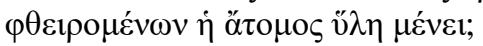

${ }^{11}$ This particle generally indicates that Simplicius is expressing his own opinion. See Fleet (in de Haas/Fleet 2001, 140 n. 29) and, more thoroughly, Menn (in Menn/Barney forthcoming, 26). I thank Stephen Menn for sending me the unpublished draft. 
forms." ${ }^{12}$ As Simplicius has already stressed, "matter in itself” (ט̋ $\lambda \eta \kappa \alpha \theta$ ' $\left.\alpha \dot{\tau} \eta \dot{v}\right)$, i.e., prime matter, is common. Individual matter, by contrast, is individual precisely because it exists in conjunction with an individual form. Simplicius here explicitly mentions individual forms. Moreover, in what immediately precedes this statement he relates "my matter" to "my form." "My form" must refer to an individual form, because Simplicius says that it is perishable. The example of "my form" shows that Simplicius is thinking of substantial forms.

The rest of Simplicius' argument reads as follows:

For individuals which are different in number are made multiple by divisions and differences in their accidents. But division and number and accidents are not peculiar features of matter, but rather of forms. Therefore this common deviation from being, or what matter is, does not come to be or perish. But the [particular] deviation and matter of this sort, which is eventually checked by form and individualised, is what comes to be and perishes just like individual form. ${ }^{13}$

Simplicius here examines the difference between common and individual matter and concludes that the latter comes to be in interaction with form. Individual matter only exists in the compound. Simplicius further explains that the constitution of several individuals depends upon two factors: (1) division and (2) a difference in accidents. Individual forms individuate matter by means of what is peculiar ( $(i \delta 1 \alpha)$ to them, i.e., by means of the divisions and accidents $(\sigma \nu \mu \beta \varepsilon \beta \eta \kappa o ́ \tau \alpha)$ that are connected with them. I take it that Simplicius additionally calls number a peculiar feature of form because matter, as a continuous substrate, cannot be counted. We can count individuals because they are discrete, and their being discrete depends on their having a form. ${ }^{14}$

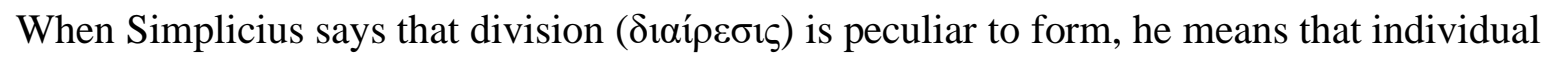
forms actually divide a continuous substrate, matter, into discrete units, the compounds. De Haas ${ }^{15}$ in his interpretation of Simplicius' In Phys. I 7, 230.29-33, argues that Simplicius carefully distinguishes between matter as undetermined extension on the one hand and form

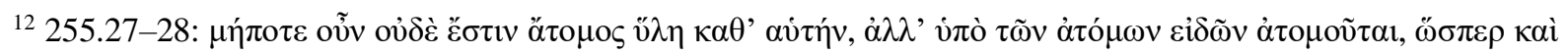

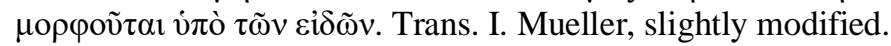

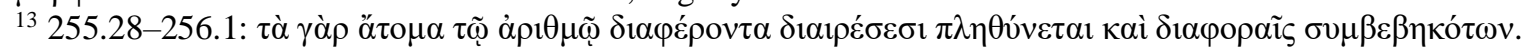

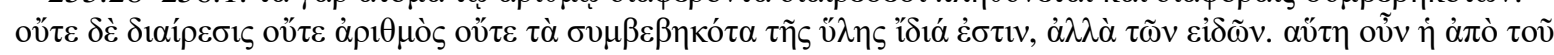

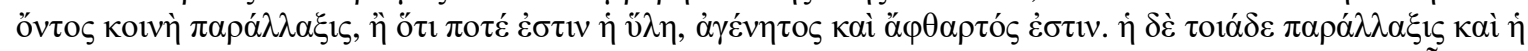

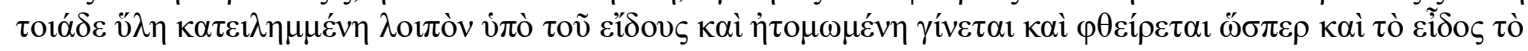

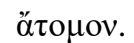

${ }^{14}$ Interestingly, Alexander at Quaestio II 28, 78.1-6, suggests a perspective on individuation very much in

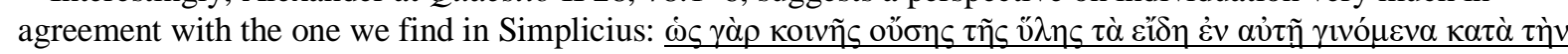

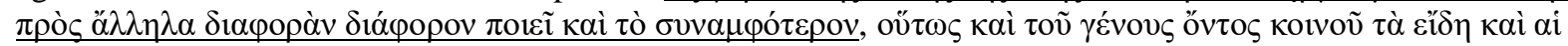

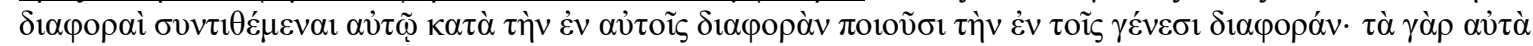

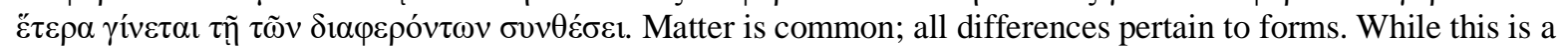
traditional Aristotelian tenet, I think it worth noting that Simplicius here uses it in order to argue against the position that individual matter is eternal. Alexander can be interpreted as defending this view in the very same quaestio (see n. 8 above).

${ }^{15}$ De Haas (1997) 116 with n. 225.
} 
as determinate measure on the other. If matter is completely undetermined, it can only provide the possibility of division, not actual division. ${ }^{16}$ The forms, then, actually divide the bare extensionality with which Simplicius identifies matter. ${ }^{17}$ The present passage from In Phys. I 9 supports de Haas's interpretation because Simplicius here says that the division that results in several particulars is peculiar to form. According to Simplicius, matter provides a divisibility that the partless forms do not have, ${ }^{18}$ while the forms cause an actual division that matter cannot bring about. Thus, both form and matter play a part in the individuation of a material substance.

At first glance, Simplicius' claim that individual forms individuate matter suggests that these forms exist individually even before they combine with matter. This, in turn, suggests that form is individuated by some other factor before it enters matter. However, it remains open what this individuating factor could be. Also, given that Simplicius conceives of immaterial forms as partless and indivisible, ${ }^{19}$ it is difficult to explain how the universal species-form could be divided into several individual forms prior to its combination with matter. I therefore assume that Simplicius is not thinking of immaterial individual forms. Instead, he means individual forms as they exist in matter-form compounds. He says that these enmattered instantiations of the universal species-form individuate matter because he wants to emphasize that form takes the leading role in individuation. Both matter and form are required to constitute an individual - but Simplicius assigns the passive role to matter, while he assigns to form the active role of dividing the substrate and endowing it with properties.

Simplicius' theory of individuation is strongly shaped by his fidelity to Aristotelian tenets. At In Phys. I 7, 226.21-22, for instance, Simplicius points out that for Aristotle form rather than matter is a particular thing ( $\tau$ ó $\delta \varepsilon \tau \imath)$. He further explains that matter cannot be a particular thing because it "has no difference relative to anything since every difference is a formal

\footnotetext{
${ }^{16}$ See also the broader context of the passage (Simpl. In Phys. I 7, 225.22-233.3).

${ }^{17}$ Simplicius' argument might be inspired by Aristotle's Physics III 7, 207a33-b1. See also Simplicius' commentary on that passage (In Phys. 504.3-22) and Soulier (2014) 63-66.

18 This is paralleled by Philoponus, De aeternitate mundi contra Proclum XI 8, 440.6-18. Philoponus there argues that the individuation of one species into several particulars necessitates matter because the $\varepsilon \tilde{i} \delta$ o $\zeta$ taken by itself does not have parts. Instead, the $\varepsilon \tilde{i} \delta o \zeta$ is divided along with its divisible substrate. As de Haas (1997) 118 n. 237 points out, عĩ்os is ambiguous here, denoting both 'form' and 'species.' De Haas (1997) 118 n. 237 concludes: "Hence the division of the species into individuals coincides with the division of the transcendent form into immanent forms under the influence of its substrate."

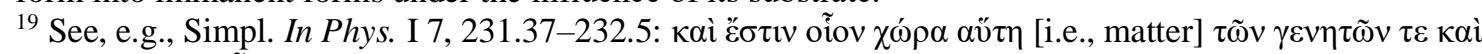

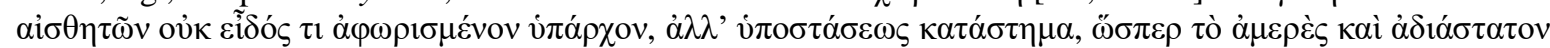

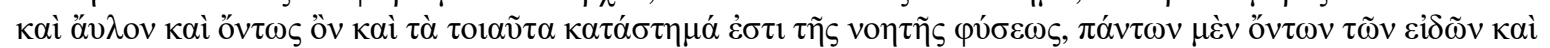

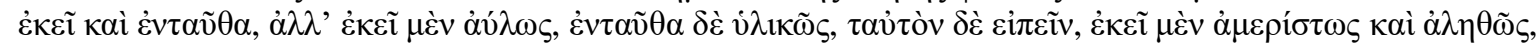

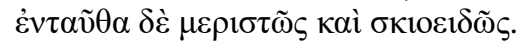


quality." ${ }^{20}$ Interestingly, though, Simplicius mingles this Aristotelian notion of matter with Neoplatonic doctrines. He holds that matter occupies the lowest rank in the ontological hierarchy. It "departs from Being and much more from the One" and does not have being proper but merely a reflection of being. ${ }^{21}$ The ontological status of matter (in Aristotelian as well as in Platonic metaphysics) thus prompts Simplicius to attribute the key role in individuation to form.

If individuation is conceived as the division of a continuous substrate, then it suffices to assume that the individual forms that individuate matter are numerically distinct instances of one and the same species-form. However, in addition to the numerical distinction of several individuals, Simplicius wants to account for the fact that individuals differ not only numerically but also with regard to their accidents $(\sigma \nu \mu \beta \varepsilon \beta \eta \kappa o ́ \tau \alpha)$. In fact, the numerical discrimination goes hand in hand with differences in accidents. Like the division of the substrate, the difference in accidents, too, is connected to form rather than to matter. To be precise, the accidents are proper to form rather than to matter.

This is not to say, though, that individuating accidents (i.e., accidents that are peculiar to one individual and distinguish it from other individuals of its species) are part of its individual form. Instead, I think that Simplicius' statement needs to be understood along the following lines: given that all accidental properties are formal rather than material, ${ }^{22}$ it is the individual forms, rather than matter, that coordinate the accidental properties and thus guarantee the unity of the individual. Hence, the link between form and accidental properties does not necessarily conflict with the view that the individual forms are numerically distinct instances of one and the same species-form. I will further elaborate on this point in the next two sections. Section 2 is devoted to the role that the accidents play in individuation. Section 3 will then elucidate the relation between the accidents and form.

\section{Individuation through accidents}

The passage from In Phys. I 9 is not the only place where Simplicius talks about individuation through $\sigma v \mu \beta \varepsilon \beta \eta \kappa o ́ \tau \alpha$. There are several passages in his commentary on the Categories where he addresses the issue more directly. The most important of these is to be found at In Cat. 3,

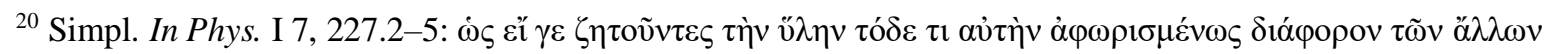

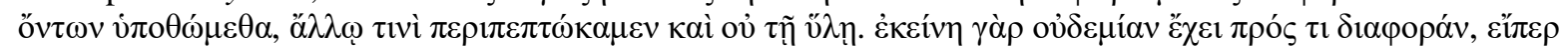

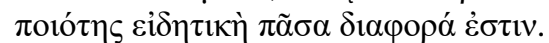

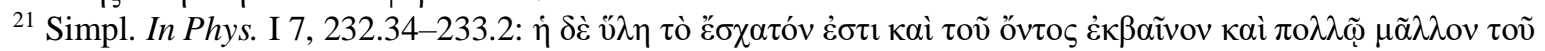

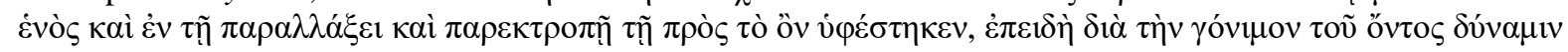

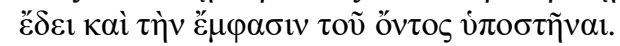

${ }^{22}$ Simplicius at In Phys. I 7, 227.2-5, (quoted in n. 20 above) says that matter does not have any individuating

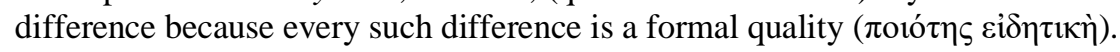


54.24-55.5. There Simplicius deals with Aristotle's characterization of the relation between genus and differentia. He begins by elucidating the notions of genus and differentia, respectively. Following Porphyry, Simplicius argues that the term genus has many meanings. He specifies the notion of genus that is relevant for the present argument and contrasts it with the notions of species and differentia:

The genus which has been taken up here is that which is predicated essentially of many things which differ in species; whereas the species is that which is predicated essentially of several things differing in number, and the differentia is that which is predicated qualitatively of several things which differ in species. ${ }^{23}$

Since these definitions presuppose a clear conception of 'differing in species' and 'differing in number,' Simplicius defines these two notions too:

Now, those things differ in species which have become distinguished from each other in the account of their essence. Those things differ in number, by contrast, which have determined the characteristic property of their own existence by means of a concourse of accidents. ${ }^{24}$

When two things differ in species, they have different definitions. Simplicius uses the

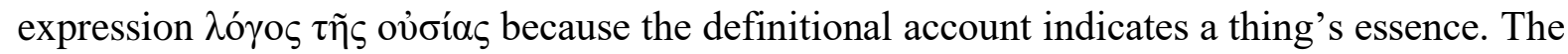
definition captures the thing's true being qua member of its species. Now Simplicius juxtaposes things that differ in species with things that differ in number. In the latter case, he does not speak of an essence but of "the characteristic property of their own existence"

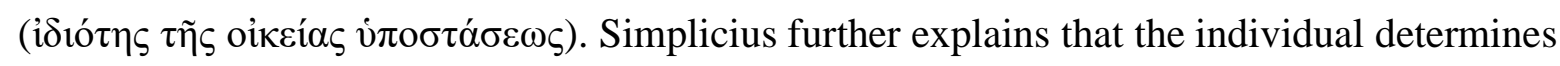
its characteristic property "by means of a concourse of accidents." In other words, a certain combination of accidents distinguishes one individual from another individual of the same species and accounts for the fact that they are each one in number. ${ }^{25}$ As Simplicius states at the beginning of the passage,${ }^{26}$ he relies on Porphyry's Isagoge. He approvingly adopts Porphyry's doctrine that the individual is characterized by a unique conglomeration of proper features. $^{27}$

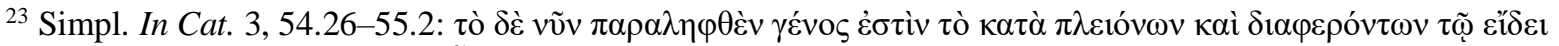

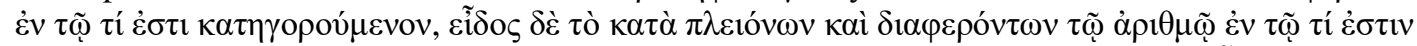

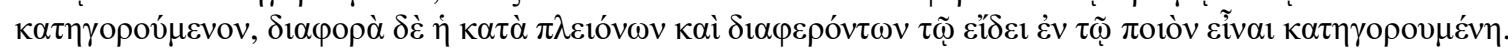
Trans. M. Chase, slightly modified.

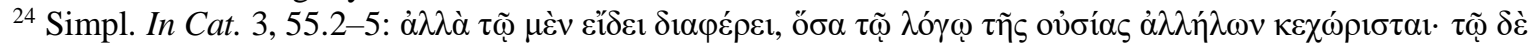

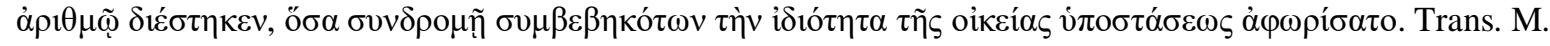
Chase, slightly modified.

${ }^{25}$ Simplicius here deviates from Dexippus' In Cat. 30.20-34. The latter rejects individuation through properties. He argues that what makes the individual an individual is its (mere) countability (see Chiaradonna 2000, 304305; Rashed 2010, 158-160) and that individuals are countable because they are separate ( $\delta 1 \varepsilon \sigma \tau \eta \kappa o ́ \tau \alpha$, see Sorabji 2004, 171.

${ }^{26}$ See Simpl. In Cat. 2, 54.25-26.

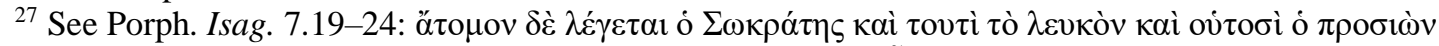

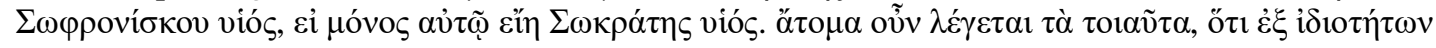


Simplicius uses this theoretical framework at least twice in his commentary on Categories 8.

One of these passages contains interesting parallels with the passage from In Phys. I 9 that we

have analyzed in section 1 of this paper. It runs as follows:

We esteem more highly than all others Aristotle's admirable doctrine of Quality; not only is it declared that Quality is incorporeal, in that bodies are distinguished by their differences according to Quality; but also, when he says that qualified people are spoken of in terms of their qualities, he defines qualities as logoi that give form to the qualified, while, when he says that the qualities are present in the qualified men themselves, he then asserts firmly that the logoi too co-exist along with the matter in matter although existing per se. For the qualified would not be said to exist because of them, if in fact they were entirely of matter and did not stand on their own when giving existence to matter and in this way existed alongside it separately.$^{28}$ But since people are said to be called individuals of such a sort because of quality, and are distinguished, individual by individual, in partition, the logos of qualities will also be found in division. ${ }^{29}$

As is well known, Categories 8 deals with the accidental category of quality. In the passage quoted above, Simplicius offers a general interpretation of Aristotle's account of quality. Without investigating all details of Simplicius' intricate interpretation, I would like to highlight a few points that are relevant to our question of individuation.

Unlike the Stoics, Simplicius holds that quality is incorporeal, and he attributes this view to Aristotle as well. ${ }^{30}$ More precisely, qualities are reason principles ( $\lambda$ ó $\left.\gamma o \mathrm{l}\right)$ that give form to the qualified. Although they exist in matter, they are self-subsisting entities. This description, which might apply to other accidental categories as well, accords with our analysis of the passage from In Phys. I 9 in the previous section. There we have seen that Simplicius conceives of all accidental differences as formal rather than material. Moreover, Simplicius assumes that "bodies are distinguished by their differences according to Quality." In principle,

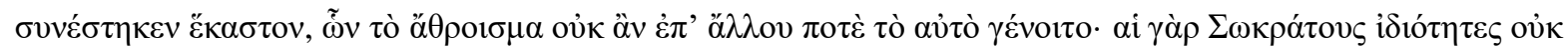

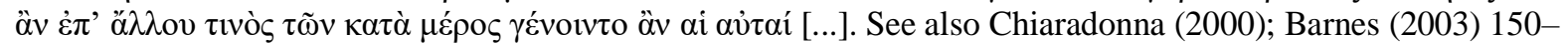
154, 314-316, 342-345; Chase (2003) 135 n. 573; Sorabji (2004) 165-166, 169; Rashed (2010) 157-158; Chase (2011) 22-24.

${ }^{28}$ Although there is no variant reading for $\chi \omega \rho t \sigma \tau \tilde{\omega} \varsigma$ in 218.13 (rendered by Moerbeke as separatim), it is tempting to conjecture $\alpha \chi \omega \rho$ pí $\tau \omega \varsigma$ and to translate '[...] existed inseparably with it.'

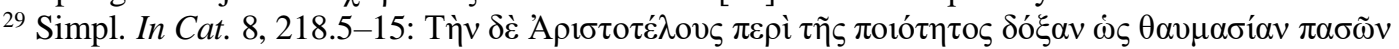

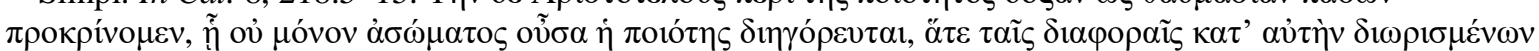

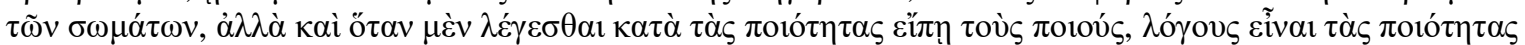

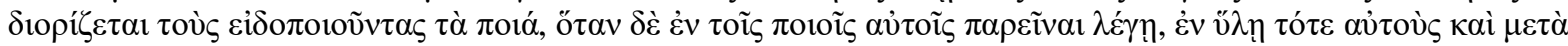

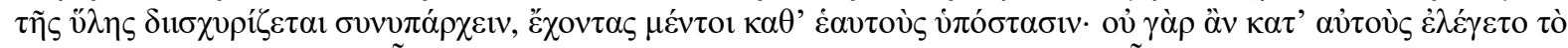

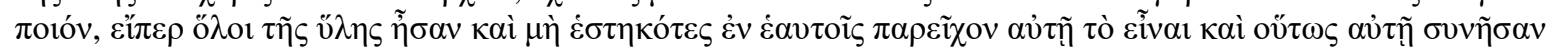

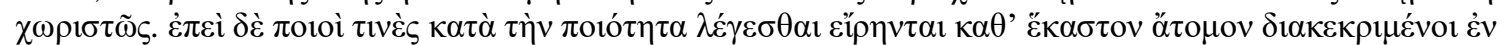

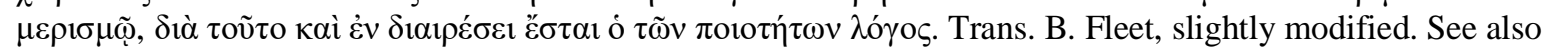
Simpl. In Cat. 8, 229.12-18, where Simplicius investigates the difference between state ( $\check{\xi} \xi \varsigma)$ and condition $(\delta i \alpha \dot{\theta} \varepsilon \sigma 1 \varsigma)$. He argues that they do not differ from each other in the way species do because they are not distinguished by specific differentiae. Nor do they differ from each other in the way two individuals do, because in their case we do not find individuating bundles that account for a numerical discrimination: $\dot{\alpha}^{\prime} \lambda \lambda^{\prime}$ ov̉ $\delta \dot{\varepsilon} \dot{\alpha}_{\rho} \theta \mu \tilde{\omega}$

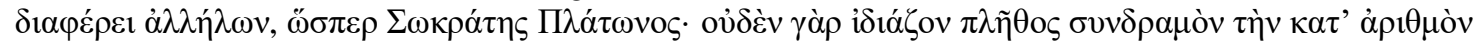
$\delta ı \alpha ́ \sigma \tau \alpha \sigma ı v \dot{\alpha} \pi \varepsilon \iota \rho \gamma \alpha ́ \sigma \alpha \tau o$ (229.16-18). This line of reasoning, too, presupposes a theory of individuation through conglomerations of characteristics. See also Porphyry In Cat. 129.4-17.

${ }^{30}$ According to Stoic doctrine, qualities are corporeal, while Platonists and Peripatetics consider them to be incorporeal, see Chiaradonna (2000) 321-322. 
this claim can be read in two ways. On the one hand, Simplicius might be using the word

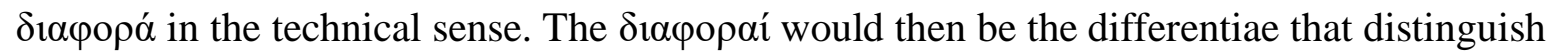
species of the same genus. Bodies would be distinguished insofar as they belong to different species. This reading presupposes that differentiae fulfill their discriminating function "according to quality," which accords with Simplicius' definition of the differentia in his commentary on Categories $3 .{ }^{31}$ However, it seems more likely that Simplicius is using $\delta 1 \alpha \varphi \rho \rho \alpha ́$ in a broader sense, denoting any kind of difference whatsoever. His use of the word here would then parallel the use we have encountered in the passage from In Phys. I 9. ${ }^{32}$ In that case, he would conceive of a distinction of individual bodies qua individual bodies. One individual body differs from another individual body of the same species insofar as it possesses different accidental properties, to be precise, it differs with respect to the accidental category of quality.

The last part of the passage confirms the latter reading. Here Simplicius explicitly refers to the question of individuation, i.e., to the question of what accounts for the distinction of one individual from another. Simplicius, once more following Porphyry, replies that it is the individual's being qualified in a certain way. The individual's being qualified, in turn, depends on quality. ${ }^{33}$ This implies that the accidental category of quality is relevant to the method of division. We can presume that accidental qualities play a role in the division of a species into individuals, parallel to the role the differentia has in the division of a genus into its species. ${ }^{34}$ This is not to say, however, that accidental qualities fulfill this role all by themselves. As has been noted, Simplicius is particularly concerned with the accidental category of quality. Given this context, his remarks should not be taken to exclude that other accidental categories, such as quantity, can be part of the individuating set of proper features too. ${ }^{35}$

\footnotetext{
${ }^{31}$ Quoted at the beginning of this section.

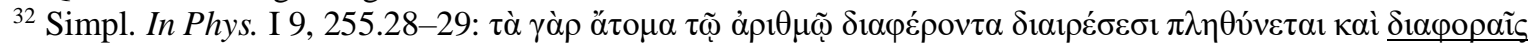
$\sigma v \mu \beta \varepsilon \beta \eta \kappa o ́ \tau \omega v$.

${ }^{33}$ On Simplicius' understanding of the relation between quality and qualified, see Hauer (2016).

${ }^{34}$ Porphyry Isag. 7.8-8.3 can be interpreted along these lines too, see Sorabji (2004) 168. On the status of differentiae in Simplicius, see Hauer (2018) 176-201. Simplicius at In Cat. 5, 98.9-12, states that differentiae are not accidents (see Hauer 2018, 179-181). According to Hauer (2018) 221, he "ascribes both a substantial and a qualitative aspect to essential qualities and differentiae."

35 Simplicius here deals with the place individuals occupy in a comprehensive predication system, and he asks which categories are relevant for assigning them this place. At the same time, he provides an ontological explanation of the relation between quality and qualified when he defines qualities as "logoi that give form to the qualified" and further remarks that "the logoi too co-exist along with the matter in matter although existing per se." The passage thus shows that too rigid a distinction between the ontological and the logico-epistemological side of the problem would be inappropriate. As Chiaradonna (2000) 308-309 has pointed out with regard to Porphyry, the logical theory of predication presupposes a certain conception of the ontological structure to which
} 
As the passages under consideration show, Simplicius adheres to the view that an individual is distinguished from other individuals of the same species by a peculiar conglomeration of accidents. The texts also show that Simplicius is heavily influenced by Porphyry, who expounds a similar theory both in his short commentary on the Categories and in his Isagoge. ${ }^{36}$ Yet, if we compare Simplicius' In Cat. with these two extant texts of his predecessor, Simplicius' commentary turns out to be a precious source, because it alone combines individuation through properties with Aristotelian hylomorphism. Simplicius' texts thus affirm that individuation through properties does not necessarily presuppose a bundle theory in the sense that the individual consists exclusively of properties. In the next section, I will further examine the relation between the peculiar conglomeration of accidents and substantial form.

\section{The two aspects of form: In Phys. II 1}

In the passage from In Cat. 8 that we have considered above, Simplicius mentions matter, but he does not mention form. In the passage from In Phys. I 9, ${ }^{37}$ by contrast, Simplicius does refer to form: individual forms shape and individuate matter by division, number, and accidents, which are all peculiar features of form. Still, he does not explain how exactly he conceives of the relation between substantial form and individuating accidents. In what follows, I will elucidate this point by drawing on an interesting passage from In Phys. II 1. Aristotle in Physics II 1 examines the notion of nature ( $\varphi v ́ \sigma ı)$ ). In this context, he raises the question of whether nature is to be identified with matter or with form. The chapter is relevant for our present purposes because it also deals with form as the object of definition. ${ }^{38}$

Following Themistius' paraphrase, 39.15-17, Simplicius transforms Aristotle's reasoning that nature is form into a syllogism: "One could syllogize thus: [major:] nature is the very thing whose presence causes what exists by nature to exist by nature; [minor:] what exists by nature

\footnotetext{
predication refers. See further Hauer (2015) 178-180, who argues that, like Aristotle's Categories, Simplicius' commentary on the Categories intertwines the linguistic analysis with an ontological one.

${ }^{36}$ See Porph. In Cat. 129.4-17 and Isag. 7.19-24. Porphyry, in turn, is certainly inspired by previous authors. See Plato's Theaetetus 209C, where Socrates suggests that Theaetetus differs from other human beings by way of a certain kind of snubnosedness. In the same sentence Socrates adds "the other [characteristics] of which you

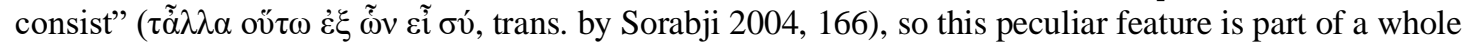
conglomeration of characteristics. See the even closer parallel to Tht. 157B-C, pointed out by Barnes (2003) 343 with n. 47 and Sorabji (2004) 165. Socrates there reports the view that we cannot predicate anything of a particular but are only able to give a bundle $(\ddot{\alpha} \theta \rho o 1 \sigma \mu \alpha)$ of qualities a certain name.

${ }^{37}$ Analyzed in section 1 of this paper.

${ }^{38}$ See Arist. Metaph. VIII 2, 1043a12-28, where Aristotle distinguishes different types of definitions, depending on whether they are related to the object's form, its matter, or both. For an interpretation of the passage in Aristotle, see Morel (2015) 115-125 with further literature. Simplicius mentions Aristotle's three types of definitions at In Phys. II 2, 296.10-13.
} 
does so by the presence of the form." ${ }^{39}$ Simplicius omits the conclusion that nature is form, because he has already mentioned it in the preceding part of the commentary. ${ }^{40} \mathrm{Up}$ to this point, Simplicius has not departed too much from Aristotle's text. Now he adds a further premise concerning the twofold character of form:

Since form is twofold - one according to the shape, the other according to the account - when we determine what each thing is, we indicate form on the one hand according to the shape alone, i.e., according to the outward figure and color and size, on the other hand according to the account, i.e., according to the uniform model of the unfolded definition; this [form] corresponds to the definition, as also does the name. This [form] also embraces the shape. Now, he says that this form according to the account or the shape of such a kind is nature. ${ }^{41}$

Unlike the preceding passage, this part of the text is not paralleled by Themistius. In the

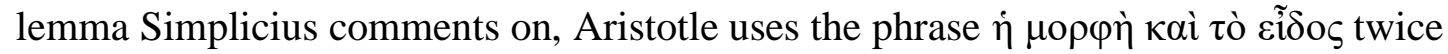

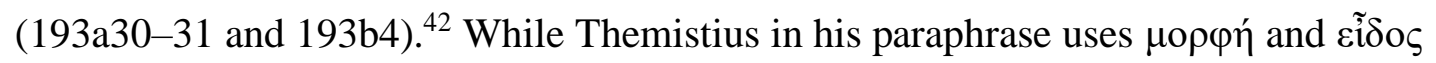
interchangeably, Simplicius here distinguishes between the two. ${ }^{43} \mathrm{He}$ explains that form is twofold, i.e., that it has two aspects: form according to the shape and form according to the account. Both of these aspects are relevant to definition.

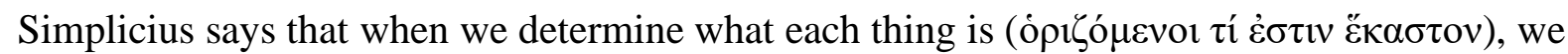
indicate ( $\dot{\alpha} \pi \circ \delta i \delta o \mu \varepsilon v)$ its form according to its two aspects. On the one hand, we indicate form

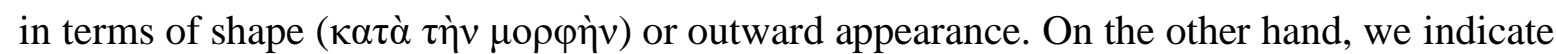

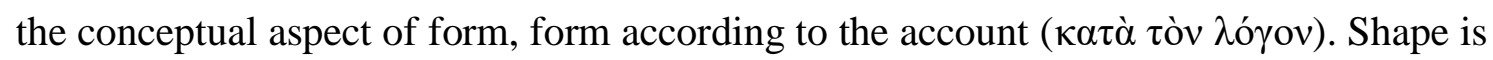
characterized by a certain outward figure, color, and size. It seems that Simplicius intentionally lists accidental features. The size, for instance, may vary from individual to individual even within one species. Simplicius' characterization of shape thus agrees with his inquiry of shape as a quality in his commentary on Categories 8, 261.17-273.4. Simplicius

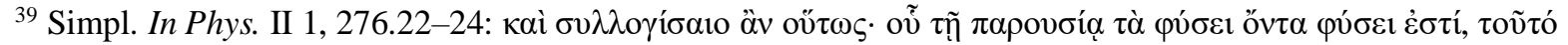

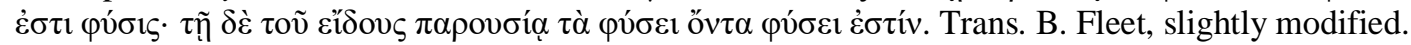

${ }^{40} \mathrm{He}$ will also refer to it in what follows, see Simpl. In Phys. II 1, 276.35-277.2: عì yò

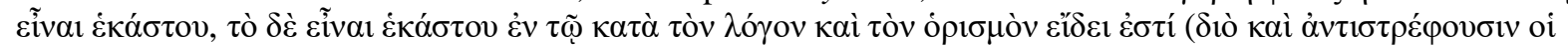

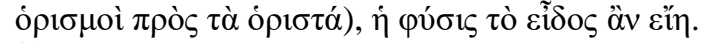

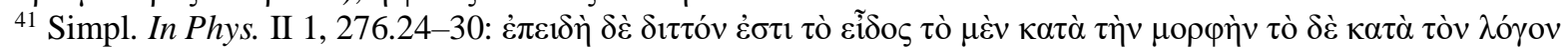

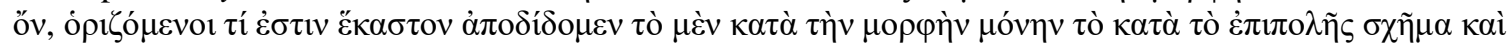

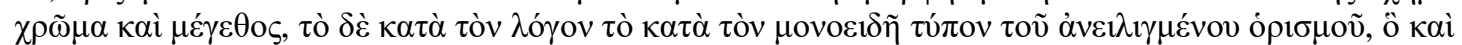

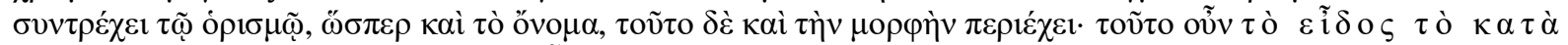

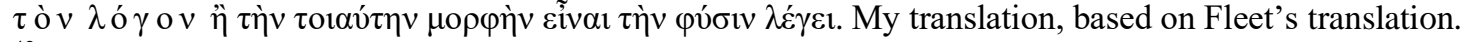

${ }^{42}$ Aristotle does not explicitly distinguish the two terms in Phys. II 1. In general, it seems difficult to grasp the semantic difference in Aristotle's works, especially since the two terms often appear together (see Stevens 2003,

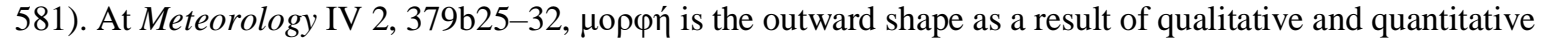
changes caused by concoction. This "nouvelle configuration de la matière," as Opsomer (2003) 380 calls it, in turn serves as the substrate for another process. Most notably, Aristotle here contrasts $\mu о \rho \varphi \eta$ with a thing's essential form ( $\left(\tilde{i} \delta \delta_{0}\right)$.

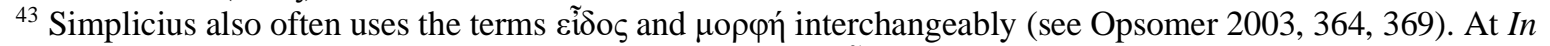

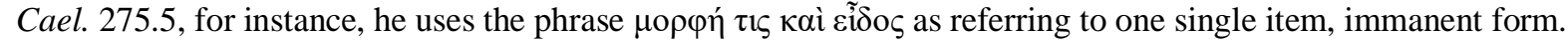


there follows Iamblichus, who holds that shape results when substantial form manifests itself individually in matter. Unlike Iamblichus, however, Simplicius in his commentary on Cat. 8 argues that shape is constituted by other qualities like figure and color ${ }^{44}$ Roughly speaking, we can say that all members of a species are the same in form, but they are not the same with regard to shape as a quality, for shape as a quality is individual. ${ }^{45}$

Furthermore, Simplicius states that form according to the account embraces the outward shape. This could be interpreted as follows: when we offer a definition in the strict sense, we indicate the form according to the $\lambda$ ó $\gamma o s$, and we do so by naming the proximate genus and the specific difference. This definition applies to all members of the species. The features that belong to shape (figure, color, size, etc.) obviously do not pertain to all members of the species. Nevertheless, the form according to the $\lambda$ ó $\gamma \circ \varsigma$ to a certain degree determines these features too. As is well-known, the extent to which accidental features like figure, color, and size can vary among individuals of the same species is limited. Substantial form sets the range of, e.g., colors and sizes that can naturally occur in individuals of a given species. For instance, although the natural color of human hair varies to a certain extent among individuals, some colors, such as blue or green, will never naturally occur in a human being. Similarly, human beings can have different heights, but they can never be 10 feet tall. The same holds true for any species, mutatis mutandis. ${ }^{46}$

When Simplicius, at the beginning of the passage, mentions the two ways of determining a thing, he uses the participle ópı́ó $\mu \varepsilon v o r$ in a broader sense. He does not mean 'defining' in the strict sense of a definition by proximate genus and differentia specifica. Instead, two different

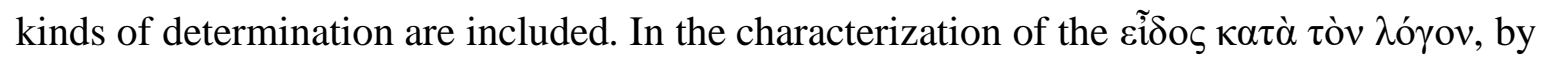
contrast, the genitive ópı $\sigma \mu$ ov denotes definition in the strict sense. This definition refers to the uniform type, the $\lambda$ ó $\gamma o \zeta$. Both kinds of determination are related to substantial form, even though they indicate different aspects of form: On the one hand, we can give a definition in the strict sense, which takes form according to the $\lambda$ ó $\gamma \circ \varsigma$ as its object. Such is the traditional definition by proximate genus and specific difference. On the other hand, we can indicate form according to the shape, i.e., we can indicate substantial form as it is manifest in matter.

\footnotetext{
${ }^{44}$ See Schwark (2018) for a more detailed analysis.

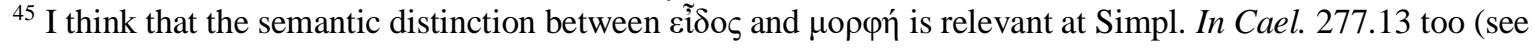
section 4.2 below).

${ }^{46}$ See Schwark (2018) 75 with n. 74. Hauer (2018) 213-214 with n. 626, too, suggests that immanent form sets limits as to which adventitious qualities a compound can assume. As far as I can see, she states this idea hypothetically, though, without adducing textual evidence.
} 
Since accidental features are listed, this manner of determining an entity differs from a definition sensu stricto.

The present passage is important because it informs us about the relation between substantial form on the one hand and the accidental features that constitute outward shape on the other. This dependency relation accounts for the range within which accidents can occur in an individual of a certain species. In this context, it is noteworthy that two of Simplicius'

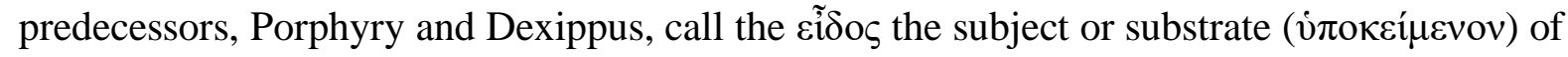
the accidents. Porphyry in his Isagoge, 17.3-6 and 21.12-15, argues that accidents are

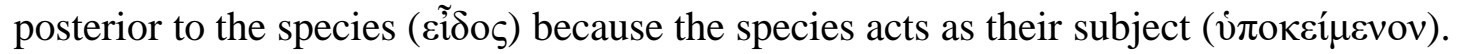
Further, in his commentary on the Categories in questions and answers, 93.12-18, he says that the accidents are in the species as in a subject. All of these three passages suggest that

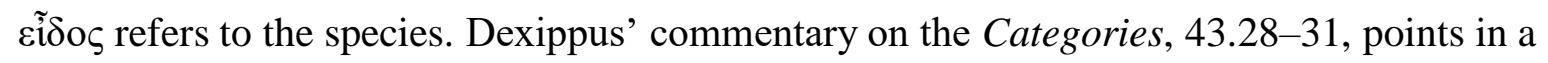
different direction. Dexippus draws an analogy between matter and form on the one hand and

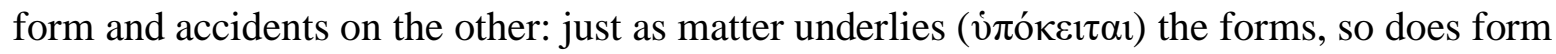
underlie the accidents.

Dexippus' commentary on the Categories is influenced by Porphyry's long commentary on the Categories (now lost) and perhaps also by his short commentary in questions and answers. ${ }^{47}$ It is therefore reasonable to assume that Dexippus either adopted his view from Porphyry or that he developed it against the background of Porphyry's theory. In short, Dexippus' statement could reflect the ontological counterpart of the theory we find in Porphyry's extant commentaries. Simplicius probably did not use Dexippus' commentary as a source, ${ }^{48}$ but it seems likely that he did use Porphyry's commentaries. ${ }^{49}$ If we presume that Dexippus' theory of the form as a substrate for accidents goes back to, or at least relies heavily on, Porphyry, and if we further presume that Simplicius, too, accepted the theory in Porphyry, then it becomes clear why Simplicius in his commentary on Physics I 9 says that the accidents are proper to form. The accidents might be proper to form insofar as the speciesform serves as the substrate for the accidents. This would accord with the limiting function of form that Simplicius sketches in his commentary on Physics II 1.

With regard to our initial question of individuation, we can draw the following tentative conclusions: Every individual possesses one instance of the universal species-form. When taken by itself, this form differs from other instances of the same species-form only

\footnotetext{
${ }^{47}$ See Dillon (1990) 8.

${ }^{48}$ See Dillon (1990) 11.

49 See Luna (2001) 301.
} 
numerically. However, the individual instance of the species-form underlies the non-essential accidents. ${ }^{50}$ These non-essential features belong to the form because it limits and coordinates them, but they are not part of the form. Within the range of possible accidents that is set by the species (e.g., no naturally occurring blue hair in human beings), the accidents can vary from individual to individual (e.g., brown hair as opposed to blond or black). The individual is the very individual that it is, precisely because it has the very accidents that it has. Shape results when the species-form individually manifests itself in matter. It includes accidental features such as a certain color and size (as opposed to the range of possible colors and sizes that is set by the species-form).

Now, where do the individuating accidents come from, exactly? In his commentary on Physics I 7, Simplicius emphasizes that qualities (and all other individuating differences) are formal. ${ }^{51}$ Furthermore, in his commentary on Categories 8 , Simplicius explains that qualities are reason principles ( $\lambda$ ó $\gamma$ or). ${ }^{52} \mathrm{~A}$ matter-form compound becomes qualified when it participates in quality as a reason principle. ${ }^{53}$ The details of this theory are intricate, partly also because Simplicius draws a distinction between essential and adventitious qualities. ${ }^{54}$ For our present purposes it suffices to note that qualities are immaterial. An example may illustrate the implications of this metaphysical framework. We can pinpoint the peculiar features of an individual material substance - of Socrates, let's say: his snub nose, his bulging eyes, his potbelly, etc. Since none of these features is part of his specific form, we might at first glance mistake them for material properties. However, according to Simplicius, these qualitative properties are strictly speaking immaterial, even though they are manifest in matter. They exist in matter, but they are themselves formal. Against this background, it makes sense for Simplicius to assume that they belong to form and are coordinated by it. ${ }^{55}$ Still, none of the passages considered so far provides an answer to the question why the individual has the very accidents it has. It therefore remains open whether the individual conglomeration of accidents is unique in the sense that no other individual with the same

\footnotetext{
${ }^{50}$ Simplicius at times distinguishes between essential and adventitious attributes. Although his discussion is not very systematic, it seems that he characterizes essential attributes as completing the subject and being inseparable from it. While adventitious attributes are labeled as accidents, the categorial status of essential attributes is controversial. See Hauer (2018) 158-159.

${ }^{51}$ See, e.g., Simpl. In Phys. I 7, 227.2-5, quoted in n. 20 above.

${ }^{52}$ See Simpl. In Cat. 8, 218.5-15, quoted in n. 29 above.

${ }^{53}$ See Hauer (2018) 213-214, 222.

${ }^{54}$ See Hauer (2018) 158-159.

${ }^{55}$ Simplicius repeatedly stresses the close relation between accidents and substantial form. He also says that form according to the shape, i.e., according to the outward appearance that is determined by accidental features, can be defined. It is unclear whether a definition of the form according to the shape differs from a definition of the compound and if so, how it differs from it (see n. 38 above).
} 
conglomeration exists or in the sense that no other individual with the same conglomeration could ever exist. ${ }^{56}$ As Sorabji remarks, both options run into philosophical difficulties.

Accepting the weaker condition that the features are not actually shared runs the risk that the individual could be reduplicated in the future. In that case, proper features are not sufficient to account for individuation. At the same time, it is difficult to explain how individuals should meet the stronger condition that their characteristic features are not shareable. ${ }^{57}$ What regulates the distribution of accidental features? How can the uniqueness of an individual's conglomeration of accidents be guaranteed? While Porphyry's stance on these questions remains unclear, Simplicius comes up with a sophisticated solution in the context of his Platonic cosmology.

\section{Do individuals have paradigms? The case of In Cael. I 9}

In his commentary on Aristotle's De Caelo I 9, 274.8-279.30, Simplicius considers the problem of individuation from a cosmological perspective. ${ }^{58}$ Here he presents an interesting solution to the question of how the individuating accidents are distributed among material substances. Simplicius' main aim is to refute Alexander of Aphrodisias' criticism of transcendent Forms. Alexander questions Plato's argument for the uniqueness of the cosmos by pointing to the multiple instantiations of other transcendent Forms. Simplicius replies to this objection that each transcendent Form has one universal immanent form corresponding to it. As will become apparent in the second part of this section, however, Simplicius also considers each individual's peculiarity as opposed to the features it shares in common with other members of its species.

At Timaeus 31A-B, Plato argues that the world must be unique because it resembles its perfect paradigm, which itself is unique. Simplicius offers a long quotation from Alexander's commentary on De Caelo, ${ }^{59}$ where Alexander argues that Plato's line of thought is inconsistent. According to Alexander, Plato posits two different kinds of relations between Forms and perceptibles. On the one hand, he establishes a one-to-one relation between the paradigm of the cosmos and the perceptible cosmos. Just as the former is unique and contains all intelligible living beings, so too is the latter unique and contains all perceptible living

\footnotetext{
${ }^{56}$ Sorabji (2004) 166, 169 raises this question with respect to Porphyry and Boethius. Both Porphyry (Isag. 7.23-24) and Boethius (In Int. ${ }^{2}$ 136.28-137.2) hold that the distinctive features cannot be shared, while Boethius (In Isag. ${ }^{2} 235.5-236.6$ ) interprets Porphyry as saying that they are not shared (see Sorabji 2004, 169).

${ }^{57}$ See Sorabji (2004) 166.

${ }^{58}$ This passage has not yet received much attention in secondary literature. Falcon (2001) and Bowen (2013) do not discuss it. Simplicius' text contains a significant number of citations from Alexander of Aphrodisias' lost commentary on De Caelo. A collection of the fragments and discussion of Alexander's arguments is offered by Rescigno (2004) 441-458.

${ }^{59}$ Discussed by Rescigno (2004) 445-452.
} 
beings. On the other hand, Plato postulates a one-over-many relation in the case of all other Forms. In the case of human being, for instance, one Form corresponds to many perceptible human beings. Alexander argues that Plato's second claim is diametrically opposed to the first. If for example in the case of the Form of man one Form corresponds to many instances, this should be possible in the case of the cosmos as well. In other words, the one-to-one relation between the Form of the cosmos and the perceptible cosmos seems inappropriate if compared with other Forms and their instances. There could be many instances of the cosmos too; these would be many in number but one in form.

Simplicius objects to Alexander's interpretation of Plato, according to which, as a general rule, many instances correspond to one paradigm. He refutes Alexander's argument in several steps. First, he adduces the counter-example of the heavenly bodies, e.g., the sun and the moon. In each of these cases, there is only one instance of the given form: the sun is literally one of a kind.

I am amazed how Alexander, in saying these things, did not understand that not all perceptible animals are such that there are many of them in accordance with each intelligible animal. For there are not many suns or many moons, but all the heavenly animals are unique. ${ }^{60}$

Simplicius here links his argument with the discussion of unique instantiation that he has offered earlier. $^{61}$

In a second step, Simplicius extends his argument to sublunary entities:

For not only are the sun and the moon single, but the man which exists for ever in the world as an image is single too, and so too is the horse, which have their being in things which are generated and destroyed; and these things are common and inseparable forms of matter, which Aristotle also accepted as being eternal, although assuredly not as prototypes. ${ }^{62}$

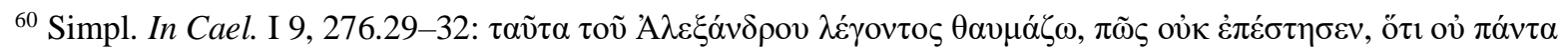

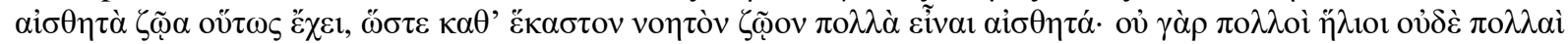

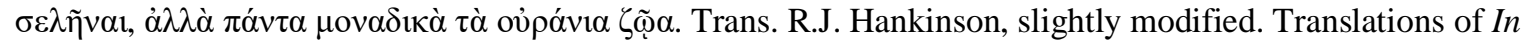
Cael. I 5-9 are Hankinson's, except where otherwise indicated.

${ }^{61}$ See In Cael. I 9, 274.10-275.21. Also, note that the present passage is reminiscent of Proclus' commentary on the Timaeus, vol. I book II, 439.22-29. There Proclus mentions counter-arguments against Plato's claim that the cosmos is unique, without, however, providing the names of his opponents. Unlike Simplicius, Proclus points to the unique instantiation of heavenly bodies as an argument against the Platonic position: the fact that sun, moon, etc. are uniquely instantiated could be used to refute the argument that the cosmos is unique because it is a whole. Sun and moon are unique, too, although they are parts, i.e., parts of the cosmos (see Rescigno 2004, 450451). Simplicius deviates from Proclus in that he uses the case of the uniquely instantiated heavenly bodies as an argument in favor of the Platonic position. Rescigno (1996) 19-29 therefore assumes that Simplicius intentionally ignores the anti-Platonic argument reported by Proclus. I doubt whether this is the case. Rescigno does not take into account that Simplicius' present argument is supplemented by two further arguments. (Rescigno disregards Simplicius' third argument altogether.) He thus misses the point of Simplicius' line of thought as a whole. For the two additional arguments that complete Simplicius' line of reasoning, see below.

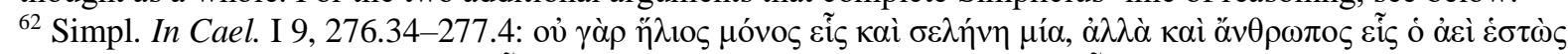

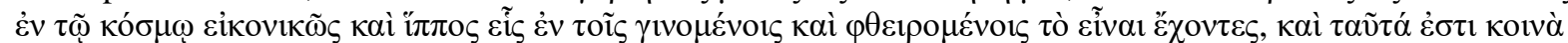

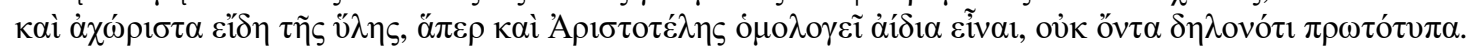


Unlike Hankinson, I hold that the image Simplicius mentions here is not "the general idea of the universal which exists in the Soul of the world." 63 The demonstrative pronoun $\tau \alpha \tilde{v} \tau \alpha$ refers back to sun, moon, and man and horse as eternal images. ${ }^{64}$ However, if we accept this reading, then Hankinson's interpretation does not make sense, because Simplicius identifies man and horse as eternal images with forms immanent in matter, not with universals on the level of the World Soul. ${ }^{65}$ The context also points in this direction. Simplicius does not even mention the World Soul here, he talks about forms immanent in matter. This becomes particularly evident in the subsequent paragraph, where Simplicius relies on the Platonic doctrine of participation. He explains that, when matter participates in form, immanent forms "are imprinted in the ultimate [i.e., material] things in virtue of their similarity to the prototypes." 66

Up to this point, Simplicius' argument only establishes that one immanent universal form corresponds to one transcendent Form. In order to refute Alexander's objection against Plato, Simplicius needs an additional argument. That is, he must explain the multiplicity of individuals that share one form, while at the same time saving his thesis that one individual corresponds to one paradigm. Simplicius begins by classifying the different characteristics a perishable particular thing possesses into common and peculiar ones:

Each of the generated and destructible things has something common, for instance being a human being, [which derives] from the single exemplar, and something particular, [which derives] from the disposition of the heavenly and the sublunary bodies changing in time, from which individuals come to be (since the disposition is itself individual even if it is productive of many things) and to which they are assimilated. ${ }^{67}$

Simplicius maintains that the commonalities among different individuals are due to the single

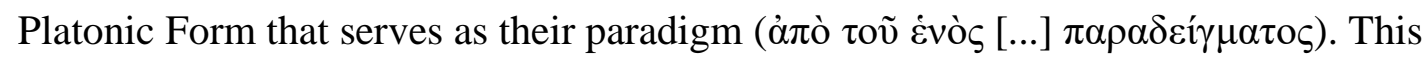
elaborates upon his immediately preceding remarks about participation, in which he distinguishes between the prototype on the one hand and the immanent form as the imprint of

\footnotetext{
${ }^{63}$ Hankinson (2004) 151 n. 505.

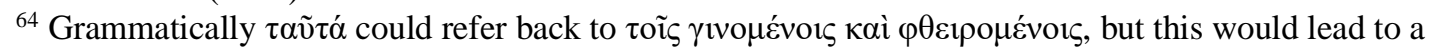
contradiction.

${ }^{65}$ Rescigno (1996) 20 seems to mean forms immanent in matter, too, though his term "idee cosmiche" is rather imprecise.

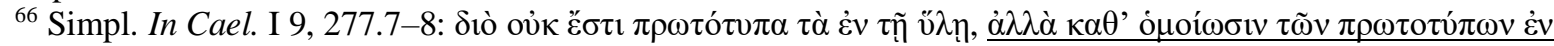

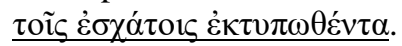

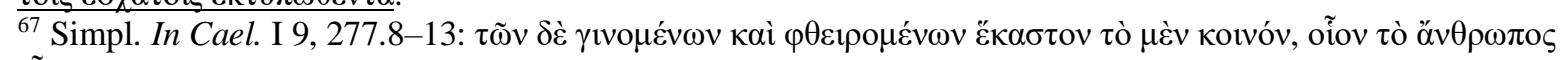

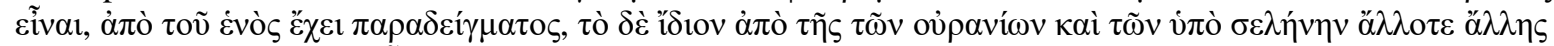

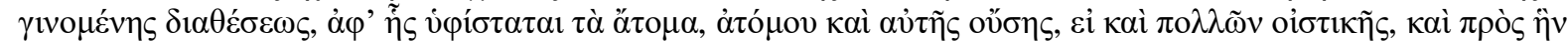
ó
} 
this prototype on the other. ${ }^{68}$ The particularity, by contrast, is due to a certain disposition ( $\left.\delta \alpha^{\prime} \theta \varepsilon \sigma 1 \varsigma\right)$. This disposition is constituted by the order of heavenly bodies and sublunary bodies at a given point in time $\mathrm{t}^{69}$

Simplicius' description of the disposition deserves special attention. I disagree with

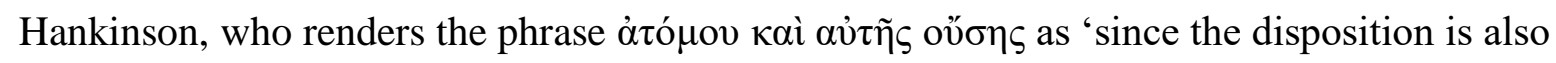
of an individual. ${ }^{70}$ Rather, the disposition from which individuals come to be is itself

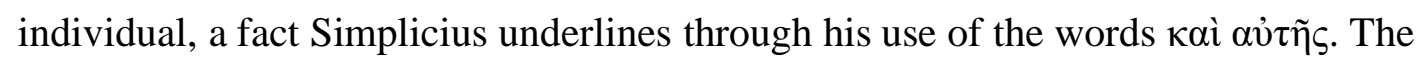
disposition's own individuality is precisely the reason why it produces individuals. ${ }^{71}$ Simplicius' argument is grounded in the so-called principle of similarity. Rosemann argues that this principle is already manifest in Aristotle's Metaphysics VII 7 and XII 3, and that it can ultimately be traced back to Plato, perhaps even to Parmenides. ${ }^{72}$ In Proclus, the principle of similarity receives the formal status of an axiom, constituting proposition 28 of the

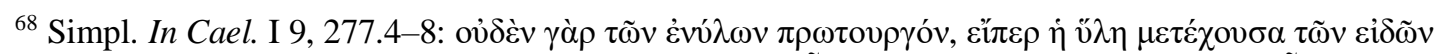

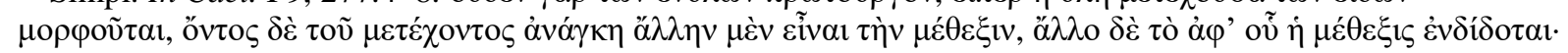

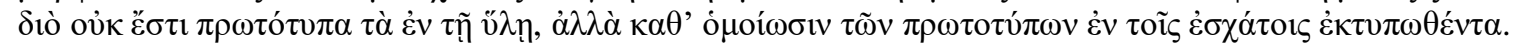
${ }^{69}$ Simplicius' argument seems to be influenced by previous authors, above all by Proclus, see Procl. In Parm. 823.25-824.3 and 825.8-14 Steel as well as d'Hoine (2010) 242-247. According to Rashed (2010) 168-170, the

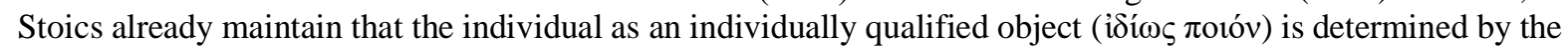
constellation of heavenly bodies at the time of its birth. See Rashed (2010) 160-164 on Alexander of Aphrodisias' criticism of the Stoic doctrine that the individual eternally returns, once per world cycle. Rashed (2010) 170-171 thinks it plausible that Alexander, too, assumes an astral influence on the individuation of material substances.

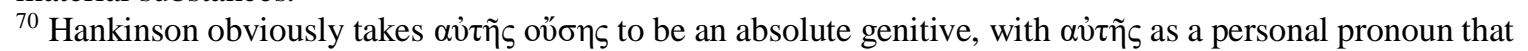

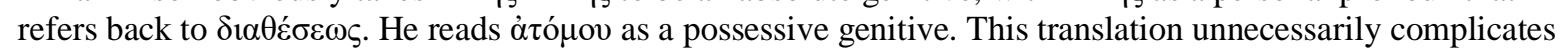

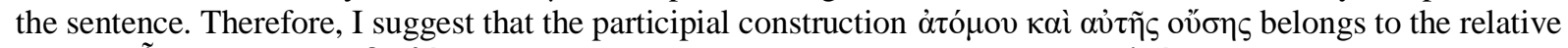
pronoun $\tilde{\eta} \varsigma$ (indirectly to $\delta 1 \alpha \theta \varepsilon \dot{\varepsilon} \sigma \varepsilon \omega \varsigma$ ) as a participium coniunctum. The adjective $\dot{\alpha} \tau o ́ \mu o v$ thus characterizes the disposition ( $\left.\delta i_{\alpha} \theta \varepsilon \sigma \iota \zeta\right)$.

${ }^{71}$ Yet, Simplicius also mentions, hypothetically, that it might be capable of producing several individuals at

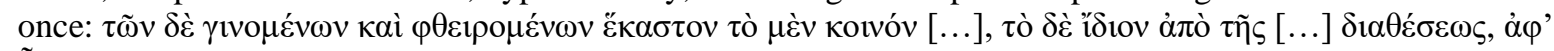

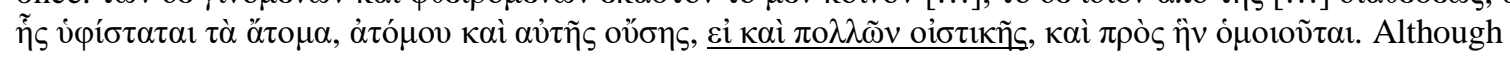
Simplicius does not explicate what he has in mind here, it is likely that he is thinking of twins and multiples. The problem of twins played a prominent role in ancient debates on astrology and individuation (see, e.g., Long 1982, 169, 173; Hegedus 2007, 53). On the one hand, Simplicius seems to indicate the possibility that twins and multiples share the same constellation. On the other hand, he introduces the phrase with a relativizing gi kaì.

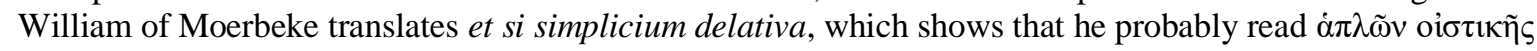
instead of $\pi \circ \lambda \lambda \tilde{\omega} v$ oi $\sigma \tau 1 \kappa \tilde{c} \varsigma$. This reading, too, is problematic because of the plural it contains. Also, the concessive ei kaì / et si is now difficult to explain, for the fact that the disposition produces simple individuals does not stand in direct contrast to its being individual. In any case, Moerbeke's variant reading indicates that the passage was perceived as delicate. The reading that corresponds to Moerbeke's translation might be a (not

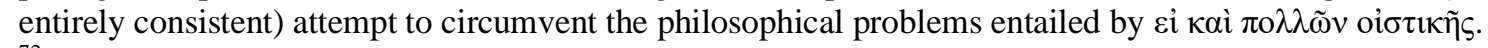
${ }^{72}$ See Rosemann (1996) 33-97. To the various passages in Plato that Rosemann (1996) 35-41 cites, one may add the characterization of the "safe cause" at Phaedo 100D-E. See Sedley (1998) 116-127, who links Plato's notion of the "safe cause" with the principle of "like causes like." Sedley additionally points to Anaxagoras" fragment B10, where the principle of similarity plays an important role. Already Barnes (1982) 119 formalizes what he calls "the Synonymy Principle of causation" as follows: "if $a$ brings it about that $b$ is $\varphi$, then $a$ is $\varphi . "$
} 
Elements of Theology: "Every producing cause brings into existence things like to itself rather than unlike."73

After having distinguished common and peculiar characteristics and their respective causes, Simplicius adds the following:

And for this reason the specialists of these issues delineate the genera, the species, and the shapes of generated things by looking to the configurations of the heavenly bodies, tracing out the similarities which the things which derive from there bear to them. ${ }^{74}$

Simplicius affirms that astrological divination indeed has its merits. ${ }^{75}$ Astrologers can use their knowledge of the heavenly constellations and make predictions about a generated

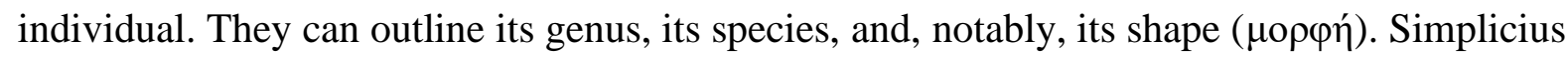

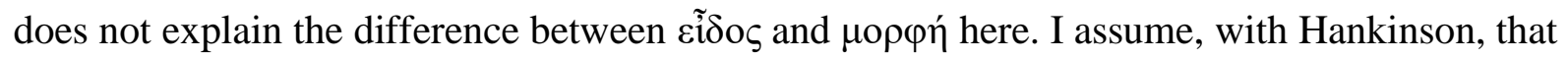
$\varepsilon \Uparrow \delta \eta \eta$ refers to species, because only if it is understood in this way is the transition from the most general to the most particular complete. The last part of the enumeration, $\mu о \rho \varphi \alpha ́ s$, then names shape as the individual manifestation of substantial form. ${ }^{76}$ The overall picture Simplicius draws here is one in which the Platonic Form accounts for the universal characteristics that belong to a genus or a species. The individual disposition, by contrast, accounts for an individual's peculiarity. It guides the interplay between form and matter that eventually leads to shape ( $\mu о \rho \varphi \eta ́)$ as the individual manifestation of enmattered form. ${ }^{77}$ In section 3, we have seen that shape comprises accidental features like figure, color, and size. Against this background, we can assume that the individual disposition determines an individual's peculiar accidental features and thus accounts for its individuality.

What does this theory have to do with the refutation of Alexander's argument? Against Alexander, Simplicius postulates a one-to-one relation even in the case of Forms like man and horse. His claim rests on the assumption that one universal immanent form corresponds to one transcendent Form. This strategy needs to be complemented, though, for Alexander anticipates the argument that the many instances of a transcendent Form are one in form. Alexander argues that even though these many instances are one in form, they do not display the one-to-one relation between Form and instance that is appealed to in the case of the

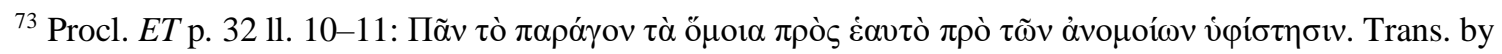
Rosemann (1996) 97 n. 97. For a discussion of this proposition, see also Opsomer (2015).

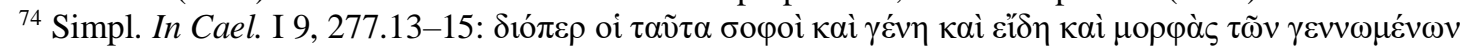

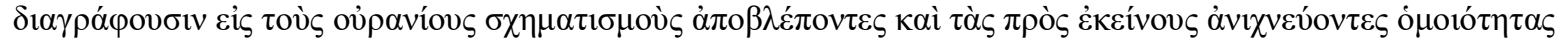

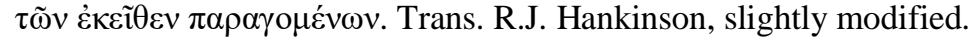

${ }^{75}$ On Simplicius' attitude toward divination, see Gabor (2014).

${ }^{76}$ On Simplicius' distinction between $\varepsilon \tilde{i} \delta o \zeta$ and $\mu о \rho \varphi \eta ́$, see section 3 above.

${ }^{77}$ On the relation between form, matter, and shape, see Simpl. In Cat. 8, 272.7-14 and 272.25-30, discussed by Schwark (2018) 72-74.
} 
cosmos. Simplicius copes with this objection by positing paradigms of another sort; on this understanding, each one of a multiplicity of individuals corresponds to one paradigm. For instance, one of the many human beings or many horses that exist in the perceptible world corresponds to one individual disposition.

The cosmic disposition thus fills an explanatory gap. It is the "immediate exemplar, one in number," of one of the many generable and destructible things. ${ }^{78}$ Ontologically speaking, however, the cosmic disposition is not on a par with a transcendent Form. While the latter is an eternal hypostatization of an essence, the former is a temporally limited set of relations within the cosmos. It belongs to the realm of nature, which implies that it can only fulfill the role of a concurrent cause. ${ }^{79}$ Since it involves sublunary entities, and since sublunary nature is not ruled by absolute necessity, ${ }^{80}$ the disposition includes contingencies.

What matters most to us is that the Platonic Form and the individual disposition share the role of a paradigm. This point is crucial because it enables Simplicius to link his hylomorphic account of individuation with Platonic ontology. The individual manifestation of immanent form depends upon the individual disposition as its immediate "paradigm." is not a transcendent cause, but it ultimately depends upon transcendent causes. ${ }^{82}$ It thus mediates between the supranatural realm and the natural world. On the one hand, it shares its role of a paradigm in common with the transcendent Forms. On the other hand, it fulfills this role on the level of nature.

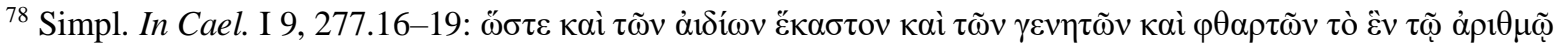

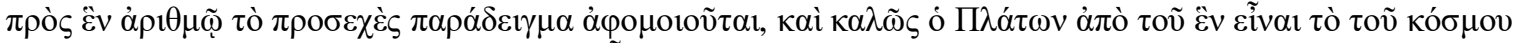

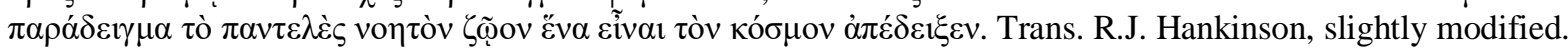
${ }^{79}$ See Simpl. In Phys. II 3, 314.9-14, where Simplicius says that nature is only a concurrent cause. Natural generation immediately depends upon the movements of the heavenly spheres. Since these are governed by psychic causes, and since on an even higher level the intelligible Forms exert their influence, natural generation

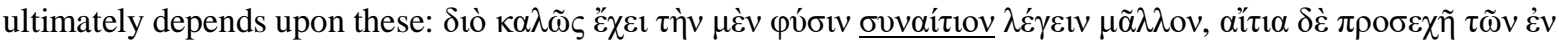

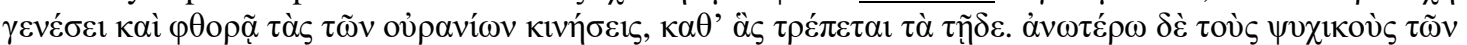

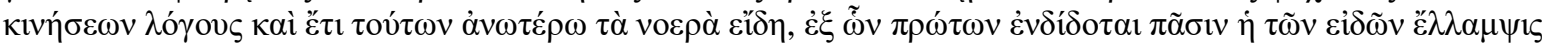

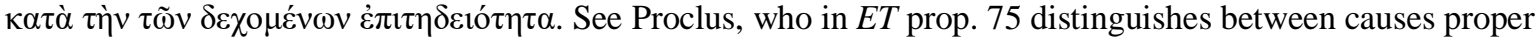
and concurrent causes $(\sigma v v \alpha i ́ \tau 1 \alpha)$. Causes proper are characterized by transcending their effects, while concurrent causes exist in the resultant.

${ }^{80}$ According to Aristotle, the sublunary nature acts always or most of the time in a determinate manner, see

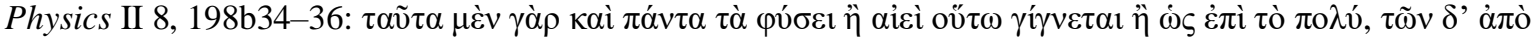

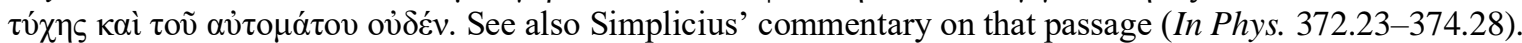

${ }^{81}$ There are two interesting parallels regarding the use of $\pi \rho 0 \sigma \varepsilon \chi \grave{\varepsilon} \varsigma \pi \alpha \rho \alpha ́ \delta \varepsilon \imath \gamma \mu \alpha$ : see Proclus In Tim., vol. II book III, 207.28-32, and Damascius In Parm. III, 169.11-13. Like Simplicius, both Proclus and Damascius use $\pi \alpha \rho \alpha ́ \delta \varepsilon 1 \gamma \mu \alpha$ as referring to something different from the Platonic Form. Still, the context is not the same as in Simplicius. Proclus argues that the harmony in the soul is the immediate paradigm of the harmony in the sensible realm. Damascius calls Cronus the immediate paradigm of the substance of the celestial bodies. Thus, unlike Simplicius, Proclus and Damascius here use $\pi \rho \circ \sigma \varepsilon \chi \grave{\varepsilon} \zeta \pi \alpha \rho \alpha ́ \delta \varepsilon 1 \gamma \mu \alpha$ for entities that transcend the natural realm. ${ }^{82}$ As Simplicius' argument at In Phys. II 3, 314.9-14, suggests (see n. 79 above).
} 
The paradigmatic function of the individual disposition is a cornerstone in Simplicius' theory of individuation. It accounts for the distribution of the accidental properties that make the individual the very individual it is. Simplicius explicitly claims that the cosmic disposition is individual. Does this also mean that it is non-repeatable? Simplicius' texts do not provide an answer to this question. We have seen that Simplicius in his commentary on the Categories adheres to the view that material substances are individuated through their proper features. This implies that no two individuals may share exactly the same properties, for if they do, it turns out that there is another individuating factor that distinguishes them from each other. It seems that the individual cosmic disposition is a means to guarantee that an individual set of properties cannot randomly be reduplicated. The idea is not new: it can be found in the Stoics, in Alexander of Aphrodisias, and in Proclus. ${ }^{83}$ The Stoics restrict the non-repeatability of the heavenly configuration, and of the corresponding conglomeration of properties in an individual, to the period between two successive conflagrations. ${ }^{84}$ Alexander, by contrast, argues that the same astral configuration could never occur twice in the course of the history of the world. ${ }^{85}$ Simplicius discusses the Empedoclean theory of world cycles at In Cael. I 10, 307.14-308.22, but he does not state his own opinion on the issue. Whatever his opinion may be, however, it is safe to say that the correspondence between the cosmic disposition and the individual enables him to account for the non-repeatability of the individual within a fixed chronological interval, e.g., within the interval of one cosmic cycle. ${ }^{86}$ In this sense, Simplicius' Neoplatonic cosmology provides the causal framework for the non-repeatability of the individual.

\section{Conclusion}

The preceding analysis has shown that Simplicius is well aware of the problem of individuation, and that he addresses it more directly than Aristotle does. While the question of whether Aristotle takes substantial form to be universal or particular remains open for debate, Simplicius explicitly claims that individual forms individuate matter. These individual forms are numerically distinct instances of one universal species-form.

\footnotetext{
${ }^{83}$ See n. 69 above.

${ }^{84}$ See Rashed (2010) 165-169.

${ }^{85}$ Alexander's position is paraphrased by Averroes, see Rashed (2010) 162-164 for an English translation of the Arabic text and for comments on that text.

${ }^{86}$ See also Plotinus, who in Ennead V 73 explains that the unfolding of all reason principles leads to different individuals, and that this unfolding of the reason principles is restricted to a cosmic cycle. Furthermore, see Simpl. In Phys. 5, 886.1-20, pointed out by Rashed (2010) 166. Simplicius there reports that the Stoics debated over whether numerically one and the same individual can recur in the next world cycle. It seems that Simplicius himself does not allow for this view.
} 
At the same time, it should be noted that the division Simplicius describes in his commentary on Physics I 9 is brought about by accidents that are peculiar to form. This accords with Simplicius' commentary on the Categories, where Simplicius adopts Porphyry's theory of individuation through proper features. Regarding the relation between individuating accidents and substantial form, Simplicius' commentary on Physics II 1 is revealing. Substantial form plays a key role as that which coordinates the individual's accidents. It sets the range of accidents that can naturally occur in an individual of a given species. In Porphyry and

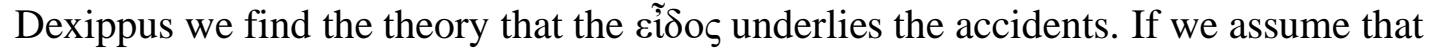
Simplicius adopts this view, we can see why he thinks of form as setting the range of possible accidents. Within the limits that are set by the species, each instance of the universal speciesform acts as a substrate for individuating accidents.

Simplicius' commentary on De Caelo I 9 sheds further light on the distribution of properties. Each natural being corresponds to an individual disposition of heavenly and sublunary bodies that serves as its immediate "paradigm." The individual disposition guarantees that the individual's conglomeration of accidental properties is non-repeatable. Simplicius' theory of individuation is thus embedded in his Neoplatonic metaphysics: as a "paradigm" on the level of nature, the individual disposition is ultimately governed by higher causes. 


\section{Bibliography}

Aubry, G. 2008. "Individuation, particularisation et détermination selon Plotin”, Phronesis 53.3, 271 289.

Baltussen, H./Atkinson, M./Share, M./Mueller, I. (trans.) 2012. Simplicius: On Aristotle Physics 1.59, with an introduction by R. Sorabji, London, Bloomsbury.

Barnes, J. (trans.) 2003. Porphyry: Introduction, translated, with a commentary, by J. Barnes, Oxford, Oxford University Press.

Barnes, J. 1982. The Presocratic Philosophers, revised edition, London et al., Routledge \& Kegan Paul.

Bossier, F. (ed.) 2004. Simplicius: Commentaire sur le Traité du ciel d'Aristote. Traduction de Guillaume de Moerbeke, vol. 1, édition critique par F. Bossier avec la collaboration de C. Vande Veire \& G. Guldentops, Leuven, Leuven University Press.

Bowen, A. C. 2013. Simplicius on the Planets and Their Motions. In Defense of a Heresy, Leiden/Boston, Brill.

Brandt, S. (ed.) 1906. Anicii Manlii Severini Boethii in Isagogen Porphyrii commenta, copiis a Georgio Schepss comparatis suisque usus recensuit Samuel Brandt, Wien/Leipzig, Tempsky/Freytag.

Bruns, I. (ed.) 1892. Alexander Aphrodisiensis: Praeter commentaria · scripta minora. Quaestiones · De Fato $\cdot$ De Mixtione, Berlin, Reimer.

Busse, A. (ed.) 1887. Porphyrii Isagoge et in Aristotelis Categorias commentarium, Berlin, Reimer.

Busse, A. (ed.) 1888. Dexippi in Aristotelis Categorias commentarium, Berlin, Reimer.

Castelli, L. M. 2003. "Individuation and Metaphysics Z 15", Documenti e studi sulla tradizione filosofica medievale 14, 1-26.

Castelli, L. M. 2013. “Universals, Particulars and Aristotle's Criticism of Plato's Forms”, in Universals in Ancient Philosophy, ed. by R. Chiaradonna \& G. Galluzzo, Pisa, Edizioni della Normale, 139-184.

Chase, M. (trans.) 2003. Simplicius: On Aristotle Categories 1-4, London, Duckworth.

Chase, M. 2011. "Individus et description", Revue des sciences philosophiques et théologiques 95.1, 3-36.

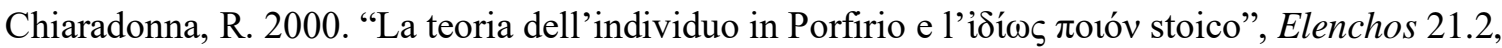
303-331.

Chiaradonna, R. 2014. "Plotinus on Sensible Particulars and Individual Essences", in Individuality in Late Antiquity, ed. by A. Torrance \& J. Zachhuber, Farnham/Burlington, Ashgate, 47-61.

Cho, D.-H. 2003. Ousia und Eidos in der Metaphysik und Biologie des Aristoteles, Stuttgart, Steiner.

d'Hoine, P. 2010. “« Ceux qui acceptent des idées de toutes choses » : Sur l'interprétation de Parménide 130b3-e4 dans l'Antiquité tardive”, Philosophie antique 10, 227-254.

de Haas, F. A. J. 1997. John Philoponus' New Definition of Prime Matter. Aspects of Its Background in Neoplatonism and the Ancient Commentary Tradition, Leiden/New York/Köln, Brill.

de Haas, F. A. J./Fleet, B. (trans.) 2001. Simplicius: On Aristotle Categories 5-6, London, Duckworth.

Diehl, E. (ed.) 1903-1906. Procli Diadochi in Platonis Timaeum commentaria, 3 vol., Leipzig, Teubner.

Diels, H. (ed.) 1882-1895. Simplicii in Aristotelis Physicorum libros octo commentaria, 2 vol., Berlin, Reimer.

Dillon, J. (trans.) 1990. Dexippus: On Aristotle Categories, London, Duckworth. 
Dodds, E. R. (ed., trans.) 1963. Proclus: The Elements of Theology, a revised text with translation, introduction and commentary, $2^{\text {nd }}$ ed., Oxford, Clarendon.

Duke, E. A. et al. (eds.) 1995. Platonis opera, tomus I tetralogias I-II continens, Oxford, Clarendon.

Erismann, C. 2014. "John Philoponus on Individuality and Particularity", in Individuality in Late Antiquity, ed. by A. Torrance \& J. Zachhuber, Farnham/Burlington, Ashgate, 143-159.

Falcon, A. 2001. Corpi e movimenti. Il De caelo di Aristotele e la sua fortuna nel mondo antico, Napoli, Bibliopolis.

Fine, K. 2001. "A Puzzle Concerning Matter and Form", in Unity, Identity, and Explanation in Aristotle's Metaphysics, ed. by T. Scaltsas, D. Charles, M. L. Gill, Oxford, Clarendon (first paperback edition), 13-40.

Fleet, B. (trans.) 1997. Simplicius: On Aristotle Physics 2, London, Duckworth.

Fleet, B. (trans.) 2002. Simplicius: On Aristotle Categories 7-8, London, Duckworth.

Gabor, G. 2014. "When Should a Philosopher Consult Divination? Epictetus and Simplicius on Fate and What Is Up to Us", in Fate, Providence and Moral Responsibility in Ancient, Medieval and Early Modern Thought. Studies in Honour of Carlos Steel, ed. by P. d'Hoine \& G. Van Riel, Leuven, Leuven University Press, 325-340.

Galluzzo, G. 2013. "Universals in Aristotle's Metaphysics", in Universals in Ancient Philosophy, ed. by R. Chiaradonna \& G. Galluzzo, Pisa, Edizioni della Normale, 209-253.

Galluzzo, G./Mariani, M. 2006. Aristotle's Metaphysics Book Z: The Contemporary Debate, Pisa, Edizioni della Normale.

Gill, M. L. 2001. "Individuals and Individuation in Aristotle", in Unity, Identity, and Explanation in Aristotle's Metaphysics, ed. by T. Scaltsas, D. Charles, M. L. Gill, first paperback edition, Oxford, Clarendon, 55-71.

Graeser, A. 1996. "Individualität und individuelle Form als Problem in der Philosophie der Spätantike und des frühen Mittelalters", Museum Helveticum 53.2, 187-196.

Hankinson, R. J. (trans.) 2004. Simplicius: On Aristotle On the Heavens 1.5-9, London, Duckworth.

Harte, V. 2010. "What's a Particular and What Makes It So? Some Thoughts, Mainly about Aristotle", in Particulars in Greek Philosophy, ed. by R. W. Sharples, Leiden/Boston, Brill, 97-125.

Hauer, M. 2015. "Simplicius on Predication", Revue de philosophie ancienne 33.2, 173-199.

Hauer, M. 2016. "Simplicius on the Relation between Quality and Qualified", Méthexis 28, 111-140.

Hauer, M. 2018. The Explanation of Qualitative Properties in Simplicius' Commentary on Aristotle's Categories, unpublished $\mathrm{PhD}$ dissertation, Institute of Philosophy, KU Leuven.

Hegedus, T. 2007. Early Christianity and Ancient Astrology, New York et al., Peter Lang.

Heiberg, I. L. (ed.) 1894. Simplicii in Aristotelis De Caelo commentaria, Berlin, Reimer.

Kalbfleisch, C. (ed.) 1907. Simplicii in Aristotelis Categorias commentarium, Berlin, Reimer.

Kirby, J. 2008. Aristotle's Metaphysics. Form, Matter, and Identity, London/New York, Continuum.

Lloyd, A. C. 1981. Form and Universal in Aristotle, Liverpool, Cairns.

Long, A. A. 1982. "Astrology: Arguments Pro and Contra", in Science and Speculation. Studies in Hellenistic Theory and Practice, ed. by J. Barnes et al., Cambridge et al., Cambridge University Press, 165-192.

Louis, P. (ed., trans.) 2002. Aristote: Météorologiques, 2 vol., deuxième tirage, Paris, Les Belles Lettres.

Loux, M. J. 1991. Primary Ousia. An Essay on Aristotle's Metaphysics $Z$ and H, Ithaca (NY)/London, Cornell University Press. 
Lowe, E. J. 2003. "Individuation", in The Oxford Handbook of Metaphysics, ed. by M. J. Loux \& D. W. Zimmerman, Oxford, Oxford University Press, 75-95.

Luna, C. 2001. "Commentaire", in Simplicius: Commentaire sur les Catégories d'Aristote. Chapitres 2-4, traduction par P. Hoffmann avec la collaboration de I. Hadot et P. Hadot, commentaire par C. Luna, Paris, Les Belles Lettres.

Meiser, C. (ed.) 1877-1880. Anicii Manlii Severini Boetii commentarii in librum Aristotelis ПЕPI EPMHNEIA 2,2 vol., Leipzig, Teubner.

Menn, S./Barney, R. (trans.) (forthcoming). Simplicius: On Aristotle Physics 1.1-2 (draft as of June 2018).

Morel, P.-M. (trans.) 2015. Aristote: Métaphysique. Livre Èta, introduction, traduction et commentaire par P.-M. Morel, Paris, Vrin.

Opsomer, J. 2003. "Aristote, Du Ciel", in Philosophie de la Forme. Eidos, idea, morphè dans la philosophie grecque des origines à Aristote, ed. by A. Motte, C. Rutten, P. Somville, Louvain-laNeuve/Paris/Dudley (MA), Peeters, 361-370.

Opsomer, J. 2015. “A Much Misread Proposition from Proclus' Elements of Theology (Prop. 28)", in The Classical Quarterly 65.1, 433-438.

Pattin, A. (ed.) 1975. Simplicius: Commentaire sur les Catégories d'Aristote. Traduction de Guillaume de Moerbeke, vol. 2, édition critique par A. Pattin en collaboration avec W. Stuyven \& C. Steel, Leiden, Brill.

Rabe, H. (ed.) 1899. Ioannes Philoponus: De aeternitate mundi contra Proclum, Leipzig, Teubner.

Rashed, M. 2007. Essentialisme. Alexandre d'Aphrodise entre logique, physique et cosmologie, Berlin/New York, de Gruyter.

Rashed, M. 2010. "Alexander of Aphrodisias on Particulars and the Stoic Criterion of Identity”, in Particulars in Greek Philosophy, ed. by R. W. Sharples, Leiden/Boston, Brill, 157-179.

Rescigno, A. (ed.) 2004. Alessandro di Afrodisia: Commentario al De Caelo di Aristotele. Frammenti del primo libro, Amsterdam, Hakkert.

Rescigno, A. 1996. Pluraliter. Due studi di cosmologia antica, Amsterdam, Hakkert.

Rosemann, P. W. 1996. Omne agens agit sibi simile. A "Repetition” of Scholastic Metaphysics, Leuven, Leuven University Press.

Ross, W. D. (ed.) 1955. Aristotle's Physics, a revised text with introduction and commentary, reprinted from corrected sheets of the first edition, Oxford, Clarendon.

Schenkl, H. (ed.) 1900. Themistii in Aristotelis Physica paraphrasis, Berlin, Reimer.

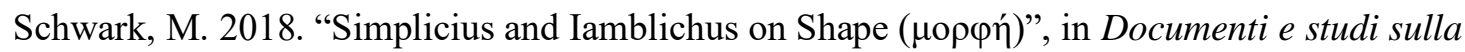
tradizione filosofica medievale 29, 59-87.

Sedley, D. 1998. "Platonic Causes", in Phronesis 43.2, 114-132.

Sharples, R. W. (trans.) 1994. Alexander of Aphrodisias: Quaestiones 2.16-3.15, London, Duckworth.

Sorabji, R. 2004. The Philosophy of the Commentators, 200-600 AD. A Sourcebook. Volume 3: Logic and Metaphysics, London, Duckworth.

Soulier, P. 2014. Simplicius et l'infini, préface par P. Hoffmann, Paris, Les Belles Lettres.

Steel, C. et al. (eds.) 2007-2009. Procli in Platonis Parmenidem commentaria, edited by C. Steel, C. Macé, P. d'Hoine, A. Gribomont, L. Van Campe, 3 vol., Oxford, Clarendon.

Stevens, A. 2003. "Aristote, philosophie théorique: essai de conclusion synthétique", in Philosophie de la Forme. Eidos, idea, morphè dans la philosophie grecque des origines à Aristote, ed. by A. Motte, C. Rutten, P. Somville, Louvain-la-Neuve/Paris/Dudley (MA), Peeters, 577-582. 
Westerink, L. G. (ed.) 2002: Damascius: Commentaire sur le Parménide de Platon, vol. III, texte établi par L. G. Westerink, introduit, traduit et annoté par J. Combès avec la collaboration de A.P. Segonds, Paris, Les Belles Lettres. 